УДК 35.182

DOI: https://doi.org/10.26642/jen-2020-3(93)-78-84

І.В. Супрунова, к.е.н., доц.

В.В. Ксендзук, к.е.н., доц.

Державний університет «Житомирська політехніка»

\title{
Детінізація економіки в контексті подолання кризових явищ, зумовлених пандемісю COVID-19
}

\begin{abstract}
Проведено критичний аналіз динаміки прогнозованих значень ВВП в Украйні та світі в умовах невизначеності. Варто зазначити, щзо глибина економічного спаду країн буде залежати від багатьох факторів, таких як: розвиток пандемії, тривалість та інтенсивність обмежувальних заходів, негативні зміни в економічних процесах, коливання на фінансовому ринку, зміни у поведінці людей. Досліджено відкориговані прогнози економічного розвитку Міжнародного валютного фонду, Світового банку, Організації економічного співробітництва $i$ розвитку (ОЕСР) на предмет зміни валового внутрішнього продукту провідних краӥн світу в результаті поширення вірусу SARS-CoV-2 з експоненціальною швидкістю. Надано порівняння прогнозів економічного розвитку на 2020-2021 рр. для України на основі оприлюднених звітів Міжнародного валютного фонду, Світового банку, Кабінету Міністрів України, Міністерства розвитку економіки, торгівлі та сільського господарства України і Національного банку України. Встановлено, щзо в умовах загострення кризової ситуації відбувається зростання частки тіньових процесів в економіці і виникає необхідність зміни інструментів та методів державного управління тіньовою економікою як структурною складовою державної безпеки, удосконалення механізму політики детінізації. Висвітлено внутрішні та зовнішні ризики, пов'язані з пандемією COVID-19. У контексті дослідження тіньова економіка розглядається у системі гарантування державної безпеки і трактується як соціально-економічне явище, якому характерна наявність неконтрольованих $і$ нерегламентованих державою, неформальних та протиправних економічних відносин, які загрожують державній безпеці країни і спричиняють економічні, соціальні та екологічні збитки державі й суспільству. Запропоновано заходи подолання кризових явищ, зумовлених пандемією COVID-19, та детінізації економіки.
\end{abstract}

Ключові слова: тіньова економіка; державна безпека; пандемія COVID-19; валовий внутрішній продукт; політика детінізаиії економіки.

Актуальність теми. Поширення пандемії COVID-19 у світі та обмежуючі заходи, які вводяться у цей час різними країнами, суттєво змінюють прогнози світової економічної активності. Значні економічні втрати спостерігаються у більшості країн світу практично у всіх галузях. Багато аналітиків дає невтішні прогнози щодо негативного впливу на світову економіку. За песимістичними прогнозами світова економіка переживатиме глибоку кризу подібну часам Великої депресії 1930-х рр. Не менш глобальні потрясіння очікують і соціальну сферу, зміни в якій корелюються з економічними.

В умовах загострення кризової ситуації відбувається зростання частки тіньових процесів в економіці і виникає необхідність зміни інструментів та методів державного управління тіньовою економікою як структурною складовою державної безпеки, удосконалення механізму політики детінізації.

Аналіз останніх досліджень і публікацій. Дослідженнями теоретичних, методичних і практичних аспектів тіньової економіки та механізмів реалізації державної політики детінізації займалося багато як українських, так і зарубіжних науковців. Серед них: В.Базилевич, С.Баранов, Г.Беккер, Д.Блейдс, А.Бойко, Дж.Б’юкенен, З.Варналій, О.Власюк, В.Геєць, О.Головатюк, Г.Гросман, І.Губарєва, П.Гутман, Б.Даллаго, Б.Данилишин, К.Дзеверіна, Л.Ебергард, Я.Жаліло, В.Засанський, В.Кислий, В.Кубатко, О.Кузьменко, С.Лєонова, І.Мазур, В.Мандибура, С.Огреба, С.Роттенберг, П.Рубін, Е. де Сото, В.Танзі, У.Тіссен, Е.Фейге, Ю.Харазішвілі, Ф.Шнайдер та ін. Однак, не применшуючи внеску вказаних вище авторів, варто зауважити, що з огляду на складну економічну та політичну ситуацію у світі в результаті пандемії COVID-19 та високий рівень тінізації економіки в Україні питання державного управління тіньовою економікою не втрачає своєї актуальності. Необхідне комплексне дослідження тіньової економіки як структурної складової державної безпеки в контексті пандемії і подолання її наслідків.

Метою статті $\epsilon$ здійснення критичного аналізу прогнозу зміни ВВП як одного із основних показників світових економічних змін і загострення кризових явищ для подальшого окреслення ризиків і комплексу заходів державної політики боротьби з тіньовою економікою.

Викладення основного матеріалу. Поточна криза, зумовлена пандемією COVID-19, $є$ дуже стрімкою і має багато нетипових характеристик, тому і варіанти подолання кризи є неоднозначними та суперечливими. Пандемія COVID-19 уже прискорила зміни технологічного укладу і окреслила початок 
нового економічного циклу, спрямованого на досягнення Індустрії 4.0. Все це передбачає прийдешню трансформацію у світовому економіко-соціальному розвитку.

Наслідками поширення пандемії коронавірусної хвороби та відповідного застосування обмежувальних і суворих карантинних заходів $є$ зниження рівня соціально-економічного розвитку, яке проявляється негативною зміною ключових показників макроекономічного розвитку. Детальніше розглянемо зміну ВВП як одного із основних і найбільш популярних показників, які використовуються для аналізу і прогнозування економічного розвитку.

За час пандемії в усьому світі станом на червень 2020 р. зафіксували понад 7 млн випадків зараження коронавірусною інфекцією. Про такі результати свідчать дані статистичної сторінки про поширення COVID-19 на порталі «Worldometer», а також дані порталу «gisanddata.maps.arcgis.com», де в режимі реального часу публікуються оновлені статистичні дані Johns Hopkins University’s Center for Systems Science and Engineering (Johns Hopkins CSSE). На планеті близько 200 країн і територій, де виявили вірус, серед них і Україна, яка посідає 35 місце. Найбільша кількість інфікованих людей у США, Бразилії, Росії, Індії та Великій Британії (рис. 1). Існує велика невизначеність щодо прогнозування економічного розвитку зазначених країн. Глибина економічного спаду країн залежатиме від багатьох факторів, зокрема, від розвитку пандемії, тривалості та інтенсивності обмежувальних заходів, негативних змін в економічних процесах, коливань на фінансовому ринку та змін у поведінці людей.

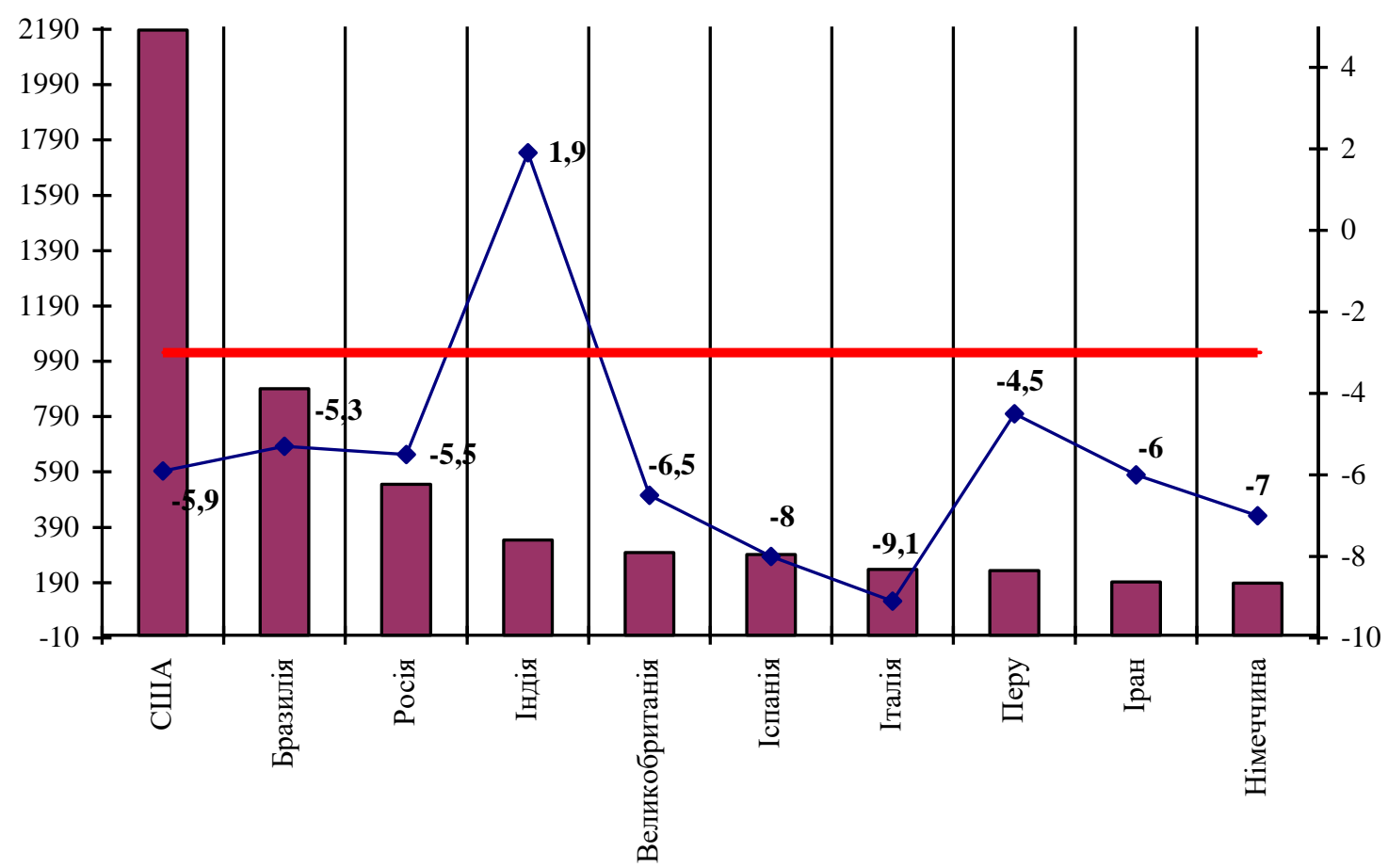

$\square$ Кількість людей, які захворіли COVID-19, від початку пандемії, тис. осіб (червень 2020)

$\prec$ Прогнозована зміна реального ВВП (GDP), \% до попереднього року

Pис. 1. Країни-лідери за кількістю зафіксованих випадків зараження на COVID-19 та прогнозовані зміни реального ВВП (GDP) зазначених крайн

Згідно з прогнозами ключових фінансових інституцій та аналітичних агентств, майже у всіх країнах 3 розвиненою економікою і тих, що розвиваються, буде спостерігатися обвал світової економіки і скорочення ВВП.

Глобальна рецесія, яка обумовлена COVID-19, призведе у 2020 р. до зниження темпів зростання валового внутрішнього продукту. У результаті пандемії прогнозується, що глобальна економіка скоротиться до -6 \% у 2020 р., що значно гірше, ніж під час фінансової кризи 2008-2009 рр. (табл. 1).

Після розгортання подій внаслідок пандемії Міжнародний валютний фонд (МВФ) знизив свої прогнози щодо росту світової економіки [1]. Так ще в січні 2020 р. МВФ прогнозував цьогоріч зростання світової економіки на 3,3\%, проте згідно зі скоригованим у квітні 2020 р. прогнозом очікується 
скорочення на 3 \% без будь-яких сценаріїв зростання і за умови наявності численних ризиків. Під час продовження епідемії у 2021 р. глобальна економіка відчує ще більш глибоке падіння (на 8 \%).

Таблиия 1

Динаміка валового внутрішнього продукту (GDP), \%

\begin{tabular}{|c|c|c|c|c|c|c|c|}
\hline \multirow{2}{*}{$\begin{array}{c}\text { Міжнародна } \\
\text { організація }\end{array}$} & $\begin{array}{c}\text { Міжнародний } \\
\text { валютний фонд } \\
\text { (International } \\
\text { Monetary Fund) [1] }\end{array}$ & $\begin{array}{c}\text { Світовий банк } \\
\text { (The World } \\
\text { Bank) [2] }\end{array}$ & \multicolumn{3}{|c|}{$\begin{array}{c}\text { Організація економічного } \\
\text { співробітництва і розвитку } \\
\text { (OECD) [3] }\end{array}$} \\
\cline { 2 - 8 } & $\mathbf{2 0 1 9}$ & $\mathbf{2 0 2 0}$ & $\mathbf{2 0 1 9}$ & $\mathbf{2 0 2 0}$ & $\mathbf{2 0 1 9}$ & $\begin{array}{c}\mathbf{2 0 2 0} \\
\text { double-hit } \\
\text { scenario }\end{array}$ & $\begin{array}{c}\mathbf{2 0 2 0} \\
\text { single-hit } \\
\text { scenario }\end{array}$ \\
\hline Світ & 2,9 & $-3,0$ & 2,4 & $-5,2$ & 2,7 & $-7,6$ & $-6,0$ \\
\hline Свропа & 1,3 & $-7,3$ & 1,2 & $-9,1$ & 1,3 & $-11,5$ & $-9,1$ \\
\hline Німеччина & 0,6 & $-7,0$ & - & - & 0,6 & $-8,8$ & $-6,6$ \\
\hline Франція & 1,3 & $-7,2$ & - & - & 1,5 & $-14,1$ & $-11,4$ \\
\hline Італія & 0,3 & $-9,1$ & - & - & 0,3 & $-14,0$ & $-11,3$ \\
\hline Іспанія & 2,0 & $-8,0$ & - & - & 2,0 & $-14,4$ & $-11,1$ \\
\hline Великобританія & 1,4 & $-6,5$ & - & - & 1,4 & $-14,0$ & $-11,5$ \\
\hline США & 2,3 & $-5,9$ & 2,3 & $-6,1$ & 2,3 & $-8,4$ & $-7,3$ \\
\hline Канада & 1,6 & $-6,2$ & - & - & 1,7 & $-9,4$ & $-8,0$ \\
\hline Китай & 6,1 & 1,2 & 6,1 & 1,0 & 6,1 & $-3,7$ & $-2,6$ \\
\hline Японія & 0,7 & $-5,2$ & 0,7 & $-6,1$ & 0,7 & $-7,3$ & $-6,0$ \\
\hline Україна & 3,2 & $-7,7$ & 3,2 & $-3,5$ & - & - & - \\
\hline
\end{tabular}

Внаслідок різкого погіршення макроекономічних перспектив Світовий банк значно знизив прогнози щодо ВВП на рік [2]. Якщо ситуацію 3 епідемією не вдасться взяти під контроль у другій половині 2020 р., то можливим є негативний шок для глобальної економіки у оціночному розмірі $-5,2 \%$ на кінець 2020 р. За оцінками Світового банку таке скорочення економіки є найбільшим шоком після скорочення на 13,8 \% відразу після Другої світової війни. У зв’язку з цим, міжнародний інститут обстоює позицію, що глобальна криза вимагає глобальної реакції, та існує потреба у глобальній співпраці не лише у галузі охорони здоров'я, а й у сфері торгівлі, фінансів та макроекономічної політики.

За опублікованим у червні 2020 р. економічним оглядом Організації економічного співробітництва i розвитку економічна активність у результаті пандемії знизилася по всій ОЕСР. За прогнозами у світлі надзвичайної невизначеності передбачено два сценарії розвитку подій - «single-hit scenario» i «double-hit scenario», відповідно й економічні наслідки, зокрема, падіння ВВП -6,0\% і -7,6\% [3]. За першим сценарієм передбачається, що вірус поширюватиметься і залишатиметься під контролем, за другим сценарієм - друга хвиля спалахне після 2020 р. і характеризуватиметься швидким поширенням вірусу. Обидва сценарії не є оптимістичними, оскільки передбачають значні економічні втрати, тяжкі та тривалі наслідки для населення, бізнесу та урядів. Ще більш невтішним є прогноз Азійський банку розвитку (АБР) (Asian Development Bank - ADB), опублікований у травні 2020 р. в доповіді «Оновлена оцінка потенційного економічного впливу COVID-19» [4]. Згідно з цією доповіддю світова економіка в результаті впливу COVID-19 може понести збитки в розмірі від 5,8 до 8,8 трлн дол., що еквівалентно 6,4-9,7 \% світового ВВП без урахування впливу політичних заходів. Міжнародне рейтингове агентство Fitch Ratings у травні 2020 р. погіршило прогноз падіння світового ВВП у 2020 р. $з$ 3,9 до 4,6 \% [5]. При цьому наголошується, що спад у глобальній економіці близький до досягнення дна. Прогнозується, якщо не буде спостерігатися збільшення випадків захворювання на COVID-19 та триватиме послаблення карантину, то рівень економічної активності почне зростати. Проте повернення показників світової економіки до рівня, що був до початку кризи, не варто очікувати до 2022 р.

Більш оптимістичним прогноз є в доповіді «Економічне дослідження: COVID-19 наносить великий удар по світовому ВВП» Міжнародного рейтингового агентства S\&P Global Ratings, яке прогнозує падіння економіки світу в 2020 р. на 2,4 \% 3 майбутнім іï відновленням у 2021 р. на 5,9 \% [6].

Що стосується України, то пандемія COVID-19 викличе сповільнення економічної активності вище за середні загальносвітові показники. Така ситуація характерна для всіх країн Свропи, що розвиваються. Глибина економічного падіння залежатиме від того, скільки триватиме карантин в Україні. Внаслідок глобальної кризи та карантинних обмежень для подолання пандемії українська економіка скоротиться за прогнозами різних інституцій від $-3,5$ до -7,7 \% у 2020 р. (табл. 2). У червні 2020 р. МВФ вже вдруге за рік погіршив прогноз падіння ВВП України. Зокрема у квітні 2020 р. у доповіді «World Economic Outlook» прогнозувалося падіння ВВП на 7,7 \% за підсумками поточного року [1]. Проте вже в червні 2020 р. у релізі МВФ у зв'язку із затвердженням нової програми кредитування Stand-Bу для України 
передбачено падіння ВВП до -8,2 \% [7]. Прогноз відновлення української економіки в 2021 р. також був погіршений з 3,6 до 1,1%. Варто зазначити, що співпраця України з МВФ є головною передумовою збереження макрофінансової стабільності в Україні під час світової кризи.

Прогноз динаміки реального валового внутрішнього продукту (GDP) в Украӥні, \%

Таблиия 2

\begin{tabular}{|c|c|c|c|c|}
\hline \multirow{2}{*}{ Організація (установа) } & \multirow{2}{*}{ Дата прогнозу } & \multicolumn{3}{|c|}{ Україна } \\
\hline & & 2019 & 2020 & 2021 \\
\hline \multirow{2}{*}{$\begin{array}{c}\text { Міжнародний валютний фонд } \\
\text { (International Monetary Fund) [1; 7] }\end{array}$} & Квітень 2020 р. & \multirow{2}{*}{3,2} & $-7,7$ & 3,6 \\
\hline & Червень 2020 р. & & $-8,2$ & 1,1 \\
\hline Світовий банк (The World Bank) [2] & Червень 2020 р. & 3,2 & $-3,5$ & 3,0 \\
\hline \multirow{2}{*}{ Кабінет Міністрів України [8; 9] } & Жовтень 2019 р. & \multirow{2}{*}{3,2} & $3,7-4,8$ & $3,8-5,5$ \\
\hline & Березень 2020 р. & & $-4,8$ & - \\
\hline $\begin{array}{c}\text { Міністерство розвитку економіки, } \\
\text { торгівлі та сільського господарства } \\
\text { України [10] }\end{array}$ & Квітень 2020 р. & 3,2 & $-4,2$ & 2,4 \\
\hline Національний банк України [11] & Квітень 2020 р. & 3,2 & $-5,0$ & 4,3 \\
\hline
\end{tabular}

Світовий банк висловив позицію, що пандемія коронавірусної хвороби і комплекс карантинних заходів, введених для їі стримування, стали різким і масштабним шоком для світової економіки, що поглинув іiї в глибоку рецесію, якої не було з часів Другої світової війни. Відповідно до доповіді «Global Economic Prospects» Україну в 2020 р. чекає скорочення ВВП до -3,5 \% з поступовим їі відновленням у 2021 р. до 3,0 \% [2]. Україна належить до країн, в яких наслідки пандемії ускладнюються залежністю країни від експорту сировини, зовнішнього фінансування, міжнародної торгівлі. Крім того, перебої 3 доступом до первинної медичної допомоги і шкільної освіти будуть негативно впливати на розвиток людського капіталу.

Кабінет Міністрів України (КМУ) оновив макроекономічний прогноз на 2020 р., погіршивши прогноз ВВП зі зростання на 3,7 \% [8] до падіння на 4,8 \% [9]. Номінальний ВВП прогнозується на рівні 4 трлн грн, тоді як раніше він оцінювався в 4,51 трлн грн. Однак у КМУ прогнозує, що у другій половині цього року відновиться економічне зростання та триватиме протягом наступних років. Зазначається, що це може відбутися за рахунок попиту на аграрну продукцію у світі, яку експортує Україна. Оновлений макроекономічний прогноз, який передбачає падіння економіки у 2020 р. на 4,8 \% ВВП, став основою для внесення поправок до державного бюджету.

Через карантин, викликаний поширенням COVID-19, Міністерство розвитку економіки, торгівлі та сільського господарства переглянуло прогноз ВВП на 2020 р. Міністерством було підготовлено проноз консенсусного бачення майбутніх тенденцій та об'єктивної оцінки ризиків і викликів, які постали перед економікою України внаслідок світової рецесії та введення в Україні обмежувальних заходів під час боротьби з пандемією COVID-19. Відповідно до консенсус-прогнозу ВВП в Україні знизиться до -4,2 \%, майбутнє зростання прогнозується у 2021 р. до 2,4 \% [10]. Карантинні заходи вже зменшили ділову активність, споживання та зайнятість населення.

Національний банк України (НБУ) погіршив оцінку динаміки реального росту ВВП України на 2020 р. з 3,5\% зростання до 5 \% падіння, проте покращив очікування зростання в 2021 р. 34 до 4,3\% [11]. Негативний вплив пандемії на українську економіку очікується відносно короткостроковим, але досить потужним. На думку голови НБУ Я.Смолія, відсутність програми з МВФ розглядалася як основний ризик для втілення прогнозу НБУ. Варто зазначити, що в червні 2020 р. для України була затверджена програма кредитування Stand-By, яка передбачає фінансування в розмірі 5 млрд дол. терміном на 18 місяців [7]. Крім того, регулятор прогнозує, що скасування карантинних обмежень зумовить досить швидке відновлення української економіки у другому півріччі цього року. Цьому сприятиме також м'яка фіскальна та монетарна політики. Збільшення урядом бюджетних видатків на подолання кризи і заходи НБУ 3 підтримання банківської системи зменшать негативний вплив пандемії на економіку.

Варто звернути увагу на прогнозування аналітичними агентствами перспектив для вітчизняної економіки. За прогнозом рейтингового агентства Fitch Ratings, у зв'язку з кризовою ситуацією у глобальній економіці, заходами щодо стримання COVID-19 в Україні та скороченням грошових переказів з-за кордону, ВВП України в 2020 р. впаде на 6,5 \%. Експерти Fitch Ratings зазначають, що економічний шок частково буде пом'якшуватися низькою залежністю України від туризму, диверсифікованістю товарного експорту і низькими цінами на нафту. Це сприятиме відновленню української економіки до 3,5 \% у 2021 р. [12]. Міжнародне рейтингове агентство S\&P Global Ratings прогнозує падіння економіки України у 2020 р. на 5,5 \% з подальшим її відновленням у 2021 р. на $5 \%$. Аналітик J.P. Morgan прогнозує економічний спад в Україні у 2020 р. на 5,1 \% ВВП, в наступному році зростання економіки може становити $6,3 \%$. 
Таким чином, пандемія COVID-19 у першій половині 2020 р. більш негативно вплинула на економічний розвиток і відновлення буде більш поступовим, ніж планувалося. Крім того, за результатами дослідження стану тіньової економіки в Україні, що провела компанія Ernst \& Young за підтримки Mastercard у межах укладеного Меморандуму про співробітництво з Міністерством розвитку економіки, торгівлі та сільського господарства України, Національним банком України та Державною службою статистики України, четверта частина від офіційного ВВП України (23,8 \%), або 846 млрд грн, становлять тіньові операції [13]. У таких економічних реаліях актуалізується необхідність удосконалення політики протидії і боротьби 3 тіньовою економікою як загрозою державній безпеці країни. Окремі перспективи детінізації економіки та подолання кризових соціально-економічних явищ, зумовлених пандемією COVID-19, наведено на рисунку 2.

Перспективи подолання кризових соціально-економічних явищ, зумовлених пандемією COVID-19, та детінізації економіки

\begin{tabular}{|c|c|}
\hline \multicolumn{2}{|c|}{ Ризики, пов'язані з пандемісю COVID-19 } \\
\hline$\downarrow$ & $\downarrow$ \\
\hline 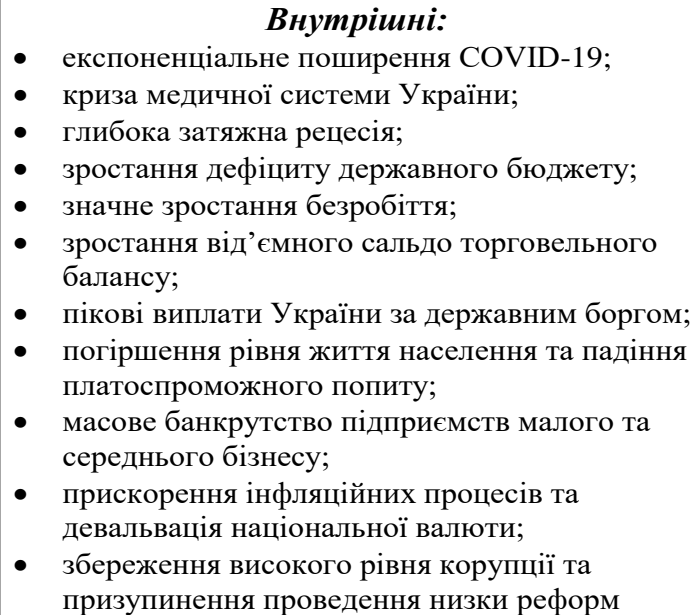 & 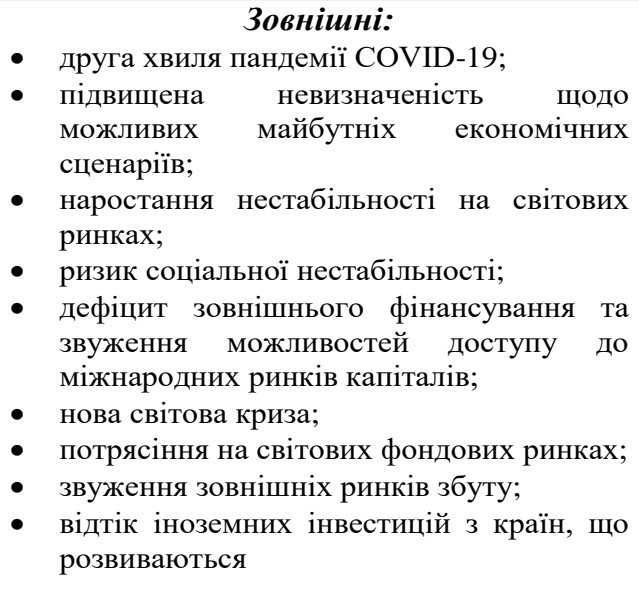 \\
\hline
\end{tabular}

Заходи подолання кризових явищ, зумовлених пандемією COVID-19, та детінізації економіки

- розробити пакет антикризових заходів, що запроваджуються з метою соціальної підтримки населення;

- розробити пакет антикризових заходів, що запроваджуються 3 метою розвитку малого та середнього бізнесу;

- боротьба з корупцією;

- вдосконалення податкової політики:

$\checkmark$ зниження і диференціація ставок податків;

$\checkmark$ податкові пільги у стратегічних для держави економічних напрямах;

$\checkmark$ усунення адміністративних перешкод для бізнесу;

$\checkmark$ диференціація системи покарання за злочини в податковій сфері;

- вдосконалення митної політики:

$\checkmark$ спрощення процедури митного оформлення та усунення адміністративних перешкод;

$\checkmark$ стимулювання експорту вітчизняної високотехнологічної продукції;

$\checkmark$ попередження порушень у сфері митного оформлення, експортний контроль;

- вдосконалення кредитної політики:

$\checkmark$ спрощення доступу до кредитних ресурсів;

$\checkmark$ зниження відсоткових ставок для бізнесу і населення;

$\checkmark$ попередження незаконних фінансових операцій, легалізації доходів, отриманих злочинним шляхом;

- підвищення ефективності державного управління;

- сприяння подальшому проведенню реформ у пріоритетних для країни сферах;

- збільшення фінансування наукових досліджень з орієнтацією на інновації;

- сприяння поширенню та популяризації використання цифрових технологій

Рис. 2. Перспективи подолання кризових сочіально-економічних явищ, 
зумовлених пандемією COVID-19, та детінізації економіки

Державне регулювання протидії тіньовій економіці та детінізації економіки реалізується 3 використанням економічних та адміністративних методів. Економічні методи політики детінізації спрямовані на забезпечення сприятливих економічних умов та прозорості інституційного середовища, в яких вигоди від тіньових економічних транзакцій будуть мінімальними. До економічних методів впливу можна зарахувати методи стимулювання, соціальної, психологічної мотивації та економічну етику. Адміністративні методи мають примусовий і в основному попереджувальний характер, вони спрямовані на подолання загроз економічної безпеки, зумовлених тінізацією економіки. Ці методи орієнтовані на попередження економічних правопорушень і понесення покарання у випадку вчинення таких злочинних та протиправних дій.

Висновки і перспективи подальших досліджень. Пандемія гострої респіраторної хвороби COVID-19, викликаної коронавірусом SARSCoV-2, стала тим фактором, який спричинив перегляд прогнозів економічного розвитку основними фінансовими організаціями та аналітичними агентствами, а уряди країн трансформувати свою економічну та соціальну політику. Світ вступає у новий трансформаційний етап, який у межах сучасної техноекономічної парадигми здійснює переорієнтацію на деглобалізацію. Застосування безпрецедентних заходів багатьма країнами, зокрема, запровадження надзвичайного стану або санітарно-епідеміологічних заходів, встановлення обмежень виїзду / в 'ізду до країн та пересування всередині країн, різке скорочення економічної активності внаслідок карантинних заходів, призвели до уповільнення економічного розвитку з прогнозованим падінням ВВП, скорочення споживчої активності населення та скорочення виробництва в усіх країнах, де зафіксовані випадки COVID-19.

У таких надзвичайних умовах спостерігається посилення ролі державного управління, тому актуальним $є$ удосконалення політики детінізації економіки та системи заходів подолання кризових явищ, зумовлених пандемією COVID-19. В Україні для ефективного вирішення завдань стабілізації соціально-економічної ситуації доцільно спиратися на комбінацію комплексу стабілізаційних заходів, зокрема, антикризових заходів, спрямованих на соціальну підтримку населення та розвиток малого й середнього бізнесу; боротьба з корупцією; вдосконалення податкової, митної та кредитної політики; підвищення ефективності державного управління; сприяння подальшому проведенню реформ у пріоритетних для країни сферах; збільшення фінансування наукових досліджень 3 орієнтацією на інновації та сприяння поширенню та популяризації використання цифрових технологій.

\section{Список використаної літератури:}

1. World Economic Outlook, April 2020: The Great Lockdown. Chapter 1 / International Monetary Fund. - 2020 [Електронний ресурс]. - Режим доступу : https://www.imf.org/en/Publications/WEO/Issues/2020/04/14/weoapril-2020.

2. Global Economic Prospects / The World Bank. - June, 2020 [Електронний ресурс]. - Режим доступу : https://www.worldbank.org/en/publication/global-economic-prospects.

3. OECD Economic Outlook / Organisation for Economic Cooperation and Development. - June, 2020. - № 107 [Електронний peсурс]. - Режим доступу : https://www.oecd-ilibrary.org/economics/oecd-economicoutlook_16097408.

4. An Updated Assessment of the Economic Impact of COVID-19 / ADB BRIEFS // Asian Development Bank. May, 2020. - № 133 [Електронний ресурс]. - Режим доступу : https://www.adb.org/sites/default/files/publication/604206/adb-brief-133-updated-economic-impact-covid-19.pdf.

5. Global Economic Outlook: Crisis Update May 2020 (Coronavirus Shock Broadens) / Fitch Raiting. - 2020 [Електронний pecypc]. - Режим доступу : https://www.floridatrustonline.com/wpcontent/uploads/2020/05/global-economic-outlook-crisis-update-may-2020-coronavirus-shockbroadens_Fitch_10123265.pdf.

6. Economic Research: COVID-19 Deals A Larger, Longer Hit To Global GDP / S\&P Global Ratings. April, 2020. - № 16 [Електронний pecypc]. $\quad-\quad$ Режим доступу : https://www.spglobal.com/ratings/en/research/articles/200416-economic-research-covid-19-deals-a-larger-longerhit-to-global-gdp-11440500.

7. IMF Executive Board Approves 18-month US\$5 Billion Stand-By Arrangement for Ukraine / International Monetary Fund. - June, 2020. - № 9 [Електронний ресурс]. - Режим доступу : https://www.imf.org/en/News/Articles/2020/06/09/pr20239-ukraine-imf-executive-board-approves-18-month-us-5billion-stand-by-arrangement.

8. Про внесення змін до постанови Кабінету Міністрів України від 15 травня 2019 р. № 555 : постанова Кабінету Міністрів України № 253 від 29 березня 2020 [Електронний ресурс]. - Режим доступу : https://zakon.rada.gov.ua/laws/show/253-2020-\%D0\%BF.

9. Про внесення змін до постанови Кабінету Міністрів України від 15 травня 2019 р. № 555 : постанова Кабінету Міністрів України № 883 від 23 жовтня 2019 [Електронний ресурс]. - Режим доступу : https://zakon.rada.gov.ua/laws/show/883-2019-\%D0\%BF\#n5.

10. Україна у 2020-2021 роках: наслідки пандемії. Консенсус-прогноз / Міністерство розвитку економіки, торгівлі та сільського господарства України. - 2020. - № 51 - 35 с. [Електронний ресурс]. - Режим доступу : 
https://www.me.gov.ua/Documents/List?lang=uk-UA\&id=767c9944-87c0-4e5a-81ea848bc0a7f470\&tag=Konsensus-prognoz.

11. Виступ Голови Національного банку Якова Смолія під час пресбрифінгу щодо рішень 3 монетарної політики / Національний банк України. - 23 квітня 2020 р. [Електронний ресурс]. - Режим доступу : https://bank.gov.ua/ua/news/all/vistup-golovi-natsionalnogo-banku-yakova-smoliya-pid-chas-presbrifingu-schodorishen-z-monetarnoyi-politiki-8486.

12. Ukraine IMF Deal Secures Funding, but Reform Is Key Challenge / FITCH WIRE. - 16 Jun. 2020 [Електронний pecypc]. - Режим доступу : https://www.fitchratings.com/research/sovereigns/ukraine-imf-deal-secures-fundingreform-is-key-challenge-16-06-2020.

13. Дослідження тіньової економіки в Україні: майже чверть ВВП - або 846 млрд гривень - перебуває в тіні / Національний банк України. - 2019 [Електронний ресурс]. - Режим доступу https://bank.gov.ua/ua/news/all/doslidjennya-tinovoyi-ekonomiki-v-ukrayini--mayje-chvert-vvp--abo-846-mlrdgriven--perebuvaye-v-tini.

\section{References:}

1. International Monetary Fund (2020), «World Economic Outlook. Chapter 1: The Great Lockdown», April, [Online], available at: https://www.imf.org/en/Publications/WEO/Issues/2020/04/14/weo-april-2020

2. The World Bank (2020), «Global Economic Prospects», June, [Online], available at: https://www.worldbank.org/en/publication/global-economic-prospects

3. Organisation for Economic Cooperation and Development (2020), «OECD Economic Outlook», No. 107, June, [Online], available at: https://www.oecd-ilibrary.org/economics/oecd-economic-outlook_16097408

4. Asian Development Bank (2020), «An Updated Assessment of the Economic Impact of COVID-19», ADB BRIEFS, No. 133, [Online], available at: https://www.adb.org/sites/default/files/publication/604206/adb-brief-133updated-economic-impact-covid-19.pdf

5. Fitch Raiting (2020), «Global Economic Outlook: Crisis Update May 2020 (Coronavirus Shock Broadens)», May, [Online], available at: https://www.floridatrustonline.com/wp-content/uploads/2020/05/global-economic-outlookcrisis-update-may-2020-coronavirus-shock-broadens_Fitch_10123265.pdf

6. S\&P Global Ratings (2020), «Economic Research: COVID 19 Deals A Larger, Longer Hit To Global GDP», No. 16, April, [Online], available at: https://www.spglobal.com/ratings/en/research/articles/200416-economicresearch-covid-19-deals-a-larger-longer-hit-to-global-gdp-11440500

7. International Monetary Fund (2020), «IMF Executive Board Approves 18-month US\$5 Billion Stand-By Arrangement for Ukraine», No. 9, June, [Online], available at: https://www.imf.org/en/News/Articles/2020/06/09/pr20239-ukraine-imf-executive-board-approves-18-month-us-5billion-stand-by-arrangement

8. Kabinet Ministriv Ukrai'ny (2020), «Pro vnesennja zmin do postanovy Kabinetu Ministriv Ukrai'ny vid 15 travnja 2019 r. No. 555», postanova No. 253 vid 29 bereznja, [Online], available at: https://zakon.rada.gov.ua/laws/show/253-2020-\%D0\%BF

9. Kabinet Ministriv Ukrai'ny (2019), «Pro vnesennja zmin do postanovy Kabinetu Ministriv Ukrai'ny vid 15 travnja 2019 r. No. 555», postanova No. 883 vid 23 zhovtnja, [Online], available at: https://zakon.rada.gov.ua/laws/show/883-2019-\%D0\%BF\#n5

10. Ministerstvo rozvytku ekonomiky, torgivli ta sil's'kogo gospodarstva Ukrai'ny (2020), «Ukrai'na u 20202021 rokah: naslidky pandemii'. Konsensus-prognoz», No. 51, 35 p., [Online], available at: https://www.me.gov.ua/Documents/List?lang=uk-UA\&id=767c9944-87c0-4e5a-81ea848bc0a7f470\&tag=Konsensus-prognoz

11. Nacional'nyj bank Ukrai'ny (2020), «Vystup Golovy Nacional'nogo banku Jakova Smolija pid chas presbryfingu shhodo rishen' z monetarnoi' polityky», 23 kvitnja, [Online], available at: https://bank.gov.ua/ua/news/all/vistupgolovi-natsionalnogo-banku-yakova-smoliya-pid-chas-presbrifingu-schodo-rishen-z-monetarnoyi-politiki-8486

12. Fitch wire (2020), «Ukraine IMF Deal Secures Funding, but Reform Is Key Challenge», 16 Jun., [Online], available at: https://www.fitchratings.com/research/sovereigns/ukraine-imf-deal-secures-funding-reform-is-keychallenge-16-06-2020

13. Nacional'nyj bank Ukrai'ny (2019), «Doslidzhennja tin'ovoi' ekonomiky v Ukrai'ni: majzhe chvert' VVP - abo 846 mlrd gryven' - perebuvaje v tini», [Online], available at: https://bank.gov.ua/ua/news/all/doslidjennya-tinovoyiekonomiki-v-ukrayini--mayje-chvert-vvp--abo-846-mlrd-griven--perebuvaye-v-tini

Супрунова Ірина Валеріївна - кандидат економічних наук, доцент, доцент кафедри економічної безпеки, публічного управління та адміністрування Державного університету «Житомирська політехніка».

Наукові інтереси: проблеми оцінки в бухгалтерському обліку; теорія, методологія та організація бухгалтерського обліку в секторі загального державного управління; державна політика у сфері детінізації національної економіки як структурної складової державної безпеки.

Ксендзук Валентина Віталіївна - кандидат економічних наук, доцент, доцент кафедри економічної безпеки, публічного управління та адміністрування Державного університету «Житомирська політехніка».

Наукові інтереси: зовнішньоторговельна політика України; участь України в міжнародних організаціях.

Стаття надійшла до редакції 16.07.2020. 